\title{
Switching to Electronic Government through Transformational Leadership: Implications of Multichannel and Digital Divide
}

\author{
Khurram Mahmood, Zainab Nayyar, Hafiz Mushtaq Ahmad \\ Department of Software Engineering \\ Bahria University, Islamabad Campus, Pakistan
}

\begin{abstract}
It is observed that to switch from the manual government processes to Electronic processes can put a huge impact in regulation of government processes, not only for the ease of government servants but also to make an effective communication mode among those processes that are taking place between government and common man. Electronic government cannot be implemented unless our leadership open heartedly accept the technological changes which will occur after adapting the electronic processes, this leadership is transformational leadership. The purpose of implementing Electronic Government is to make use of information technology not only in Government sector, but also to bring technological change in organizations by introducing new technical skills for improving service delivery, democratic processes and capacity building which provide strength and support to the Government policies. Previously government servants always work through traditional channels like front desks or telephones to fulfill customer requirements which is costly and time consuming. These consequences moved people away from digitization and automation. This study is based upon filling the gaps between E-Government and digital divide by utilizing the multi-channel services governed by transformational leaders. Results gathered through questionnaires have shown that transformational leaders along with digital channels have put a positive effect in switching from manual to Electronic Government processes. These aspects have increased the transparency, efficiency, accountability and security in Government processes.
\end{abstract}

\section{Introduction}

The explosive entrance of technology in today's world has changed every aspect of life; way of interaction, study, work, and living. The government and its agencies are also getting effected by this drastic change and taking serious note to make use of IT all over the world. Pakistan is part of global village and hence trying to cope with the technology change. By using IT techniques governments are reinventing themselves as they also want to transform and indulge them into e-businesses and certain e-processes for their economic fueling and better growth in the global world.

The change in businesses at governmental level has provided an ease to up lift the social status of its citizens and hence that was an emergence of Egovernment [1]. The integrated use of ICT in public sector organizations for improvement in their processes is known as E-government. In the digital era it is a dire need of government to automate their traditional manual processes into the sophisticated automated systems to provide E-services to the citizens of the country through E-government applications.

E-Government and digital divide are closely related as if government has implemented certain IT policies and defining and implementing the EGovernment processes in the society, but the citizens cannot make use of them efficiently then such technology fueling is of no use because people are not getting interacted with the political processes in meaningful ways.

Previously people in government organizations always work through traditional channels like front desks or telephones to fulfill their requirements. Use of traditional channels became time consuming and was designed to fulfill the requirements of a single user [4]. The use of technology became essential for people and this use gave birth to the concept of transformational leaders who always work with their subordinates, they are technically strong enough that they can make use of technology easily. The individual, who plays as a leader and transforms himself as an effective user of technology, can provide efficient and effective services to citizens with transparency through digital channels such as Egovernment applications. Even after the two decades using of E-government in governmental organizations citizens are still facing many issues related to citizen services.

The main focus of electronic government is to deliver better and efficient services to public at large with transparency and accountability at lower cost. It will increase the productivity of the government sector organizations and these citizen services may be accessed through a central gateway service. The 
e-government demands to use the new multichannels [6], i.e. internet, kiosks, mobile and Digital TV media), new infrastructure and technologies to enable transparency, accountability and openness of government organizations for the retrieval of specific information.

A composed leadership is very important factor for the e-government processes implementation and coordination within and among the departments in a speedy way and reinforcement of governance objectives [5]. The matter of fact is that egovernment is a complex issue and having many dimensions. A strong leadership is required for each dimension which will well conversant with the technology to take decisions.

This study is based upon filling the gaps between E-Government and digital divide by utilizing the multi-channel services governed by transformational leaders. The study will reveal new ways of switching to E-government by using the concept of digital channels. However transformational leadership will influence the adapting phase of this concept. The main objectives of this study are to provide easy access of e-government services with multi-channels through digital divide. The main focus of the eservices is:

a. To ensure User Interaction with technology.

b. To make accessible and flexible services (Anytime, Anywhere).

c. To analyze Multi-Channel Service delivery.

d. To explore appropriate Channel Selection without limitations.

e. To Manage Transformational Leadership for implementing electronic government to achieve transparency, accountability, effectiveness and Scalability.

\section{Literature Review}

Andrian et al. [7] examined the Software Assessment Model Using Metrics Products for eGovernment in The G2B Model. The e-government can be divided into the number of models, such as, Government to citizen or Government to customer (G2C) or Government to Government (G2G) or Government to Business (G2B) or Government to employee (G2E). They found that the government to Business (G2B) model was not much used by the researchers as compared to $\mathrm{G} 2 \mathrm{C}$. In this regard, many software applications were developed to support G2B model, but their utilization were very low due to noncompliance the need of the users or stakeholders. It was important to develop the software application which may fulfil the requirements and expectations of the end users. The purpose of their study to assess of this model using development an enhancement of metrics products from ISO 9126 for e-government to business model. The development was based on the assessment, functionality, reliability and effective usability with efficiency to develop quality software for the G2B model. Many Governments of the various countries have already using different applications to providing citizen services and they were known as egovernment. The model not only connects the citizens but also other areas such as business, customer, and organizations or connection between public bodies. The authors were proposed the application and demonstrated through a case study. They implemented the model in local government bodies. They found that the security of the application was not up to the mark and the maturity of the software was low, but functionality, operability and accuracy of the software was good enough.

Athukorala et al. [8] examined the Impact of Transformational and Transactional Leadership Styles on Knowledge Creation in Sri Lankan Software Industry. One of the main factors of leadership that affect knowledge creation in Sri Lankan software industry. They found two styles of leaderships one was transformational and other one was transactional styles were considered and their effect which need to be accessed. Organizational culture providing moderating effect on the relationship between leadership behavior and knowledge creation. The study was based on four variables two independent variables transformational and transactional and one dependent variable knowledge creation and one moderating variable organization culture. The total 150 participants were participated in the feedback. The purpose of the study to analyze the relationship between transformational leadership and transactional leadership and knowledge creation to find the organization culture. A quantitative approach was used in the study. There were 37 questions were asked in 5 different sections. The data was collected mostly from managers and software engineers. The focus of the survey was on two main variables transformational leadership and transactional leadership style. They concluded that the transformational leadership styles have more correlation with knowledge creation. It is determined by the study that the transformational leadership was the main factor that highly influenced the knowledge creation the Sri Lankan software industry.

Yin and Jiahong [9] examined the influence of the digital divide to the electronic government affairs. As a digital Divide, e-government was the process to create easy procedures to in the public administrative areas in which the e-government applications would be used and need to reduce the digital divide was the basic idea while implementing those applications. During the study the authors found that the digital divide was the biggest hindrance in the implementation of the e-government in the country. The e-government implementation 
progress was dependent on the main two degrees, first was to use the degree of the government and the second was the degree of public acceptance. The government applications were dependent on the interior and extent on the government network connection between the government and the application construction, the degree of public acceptance and infrastructure construction and network of the government, digital divide was the core issue. Digital divide was becoming the bottle neck while implementing e-government in the country and regional information gaps. They have concluded that the existence of digital divide problem was reflected in china's information and network technology application was low. They also found that in china's market the capacity of information and network application potential was very high.

Wickberg [10] conducted a survey on the impacts of E-government all over the world and identified that E-government has put a positive impact on political environment. It provided a lot of political benefits in the form of automation, transperency, detection in operations, preventive detection, awareness detection, reporting, deterrence and promoting ethical attitudes. She surveyed the due to E-governemnt inplementation $90 \%$ reduction in curroption occurred by enhancing the security, reduction in bribery and legal logging.

AL-Hussaini et al. [11] examined the impact of adopting e-government on reducing administrative corruption. Many nations, suffered from the administrative corruption, which influenced distinctive parts of life in the state's social, monetary and political corruption. The objective for the study was to answer the principle question of egovernment restrictions on managerial corruption. The study found an unfairness and partiality among groups and individuals, which were active in the forefront of the prevalent forms of corruption in government. This study found that the transition toegovernment placed limits on the intervention of individuals. Thus, it reduced, if not removed, many kinds of corruption related to individual emotion through preference. They found the factors which contributed in corruptions in the government namely monopoly power and discretionary power. The authors used to measure the corruption factor with the help of the following formula:

\section{Corruption $=$ Monopoly + discretion - accountability}

The authors established that the corruption in public sector finds the government monopoly discretion and reduction in accountability were the key factors in corruption. The researcher prepared the descriptive approach, a questionnaire, to collect the necessary data on the impact of adopting e- government. Questionnaire stability was calculated by a reliability coefficient, where the reliability coefficient $(93.5 \%)$ confirms the validity. The study sample consisted of 147 males (55.5\%) and 118 females $(44.5 \%)$. Based on the data collected through questionnaires resulted that the $88.7 \%$ population agreed that the use of e-government may help to reduce the corruption in public sector.

Choueiri et al. [12] in their study tackled the egovernment vision and its implementation strategy in Lebnon. Futhermore they enlighten the imortance of use of ICT applications in Lebnon and emphasied the use of ICT in public administration, e-government solutions etc their use and implications.

Hunnius and Schuppan [13] examined the competency requirements for transformational egovernment. In this study the authors analyzed the competency levels which required for the public sector manager that would be accompanied in egovernment and development of framework for the public sector managers. They also found that the number of factors that were became hindered towards the implementation of the e-government such as institutional factors in administrative systems, characteristics of political system and acceptance of the citizens. The main factor which was considered for delaying e-government reforms was insufficient and inadequate public sector manager's personal competency. The competency of methodology was challenging to measure. Furthermore, question of changing and newly raised competency level in the context of e-government faced some important challenges. The authors used a mixed approach descriptive and exploratory to collect data. There were total 83 participants were participated in the survey and 67 experts who were themselves in public sector or consultant or scholar from the field of e-government participated in the workshops in various countries. Based on the survey and workshops it was resulted that the most important skills for the e-government across all over the countries were project management, process management, organizational design, risk management and IS Strategy. It was also resulted that it was possible to differentiate new core egovernment skills and competencies closely related to e government of the public sector from those which were already prevalent in the public sector and "merely" now need to be applied to e-government. There were some generic government competencies include personal competencies (creativity, selfcontrol and motivation, and time management) and social competencies (leadership, cooperation and communication). The core e-government competencies which were the e-government management competencies (risk management, quality management, performance management, and contract management), e-government design competencies (organizational design, process design, 
IS design, ICT specialist, and marketing skills), eCompetencies (ICT literacy, information processing, and media skills), and e-policy competencies (estrategies and e-policies, models and concepts, and information processing law).

Similarly Chander and Sharmila [14] also conducted a survey to deal with the challenges faced by Indian Government for implementation of $\mathrm{E}$ government. They suggested to implment interoperabiliy by enforcing security and privacy policies, trust between deaprtments and common public and standardization of processes.

Mistry and Jalal [15] examined the relationship between E-government and curroption in developed and underdeveloped countries. While examining this relationship they investigated the impact of Egovernment on curroption and either the impact of egovernment is higher in developed or underdeveloped countries. They developed the empirical model named as probit model to test and examine the results on the basis of relationships between two variables from different time periods. They took a data of seven years from (2003 to 2010) and observed the change in e-government development index with the change of curroption perception index by applying the causal method. The samples were deivided into 3 different intervals from 2003 to 2008 nd from 2008 to 2010 . They found that curroption is less in those countries where egovernment usage is increased. Secodly the egovernment usage and its impacts are higher in developing countries. The results from probit method and regression method showed that $1 \%$ increase in egovernment made $1.17 \%$ decrease in curroption. The limitations on their research were that research focused the intra country comparisons and this didn't effect the each and every area of country. Secondly the conditions of curroptions affected from economic, political, historical and public sector policies of countries.

$\mathrm{Fu}$ and Xiao [16] examined the Promoting Sustainable E-Government with Multichannel Service Delivery: A Case Study. It was important to provide multi-channel for expand the services to the citizens especially in rural areas. They have further explored the operations and usage of the multichannel delivery from the local government bodies of China. The results shown that the web channels, mobile based channels and e-services kiosks were the primary delivery channels as compared to the traditional channels that can be enhancement to narrow down the digital divide. As a developing country, China having large population and it was difficult to expand infrastructure and provide online access across the country especially in the rural areas. The more attention was given to the coordination of digital and traditional channels. Based on the previous case study the e-services like e-taxation services through multi-channel delivery was launched through establishing the call center at local administration body in China. They have analyzed to explore the operations and usage of multi-channel delivery at the local administration level. The data was collected through the investigation on the local Municipal administrative service center and taxation bureau. The following questions were discussed

- For disadvantage groups in rural areas of the city, which channels help to extend access to eparticipation?

- According to the four stages of online service development, what is the distribution of existing web services delivered by the city?

- How about the usage of existing servicechannels?

They have adopted the case study as primary research method which was the most appropriate way to gather all information and experiences. Through the study they have explored the sustainability of e-taxation in the China. It was also discussed to reduce the digital divide, the development of online services and usage of multichannels.

Panda et al. [17] studied the e-procurement initiatives of Indian Government by applying exploratory research techniques. They identifies the ways through which the e-procurement initiatives can be implemented in the cost effective ways by increasing the efficiency and transperency by automating the manual processes. The research data is carried out through secondary data and case studies. It was concluded that althogh e-government plans were initiated and implemented in India but they are needed to be promoted in a sucessful manner.

Kazmi [18] examined the factors influencing egovernance Implementation: issues and challenges in Pakistan. The author used the descriptive approach and developed the questionnaire that determined the key factors which were influenced the e-governance implementation in Pakistan. The key factors would be web portal quality, technological infrastructure, government policy and human resource. EGovernment played a vital role in providing the citizen services to achieve accountability, transparency and efficiency for the smooth and reliable government management. As a result, reduction in corruption, more convince to the government and citizen to increase in growth and reduce the overall cost. The author used the quantitative type of research and which was focused on four independent variables and one dependent variable. I-ways, Digest of Electronic Government Policy and Regulation provided conceptual framework that incorporates human capacity, infrastructure development and access to information for the e-government. They concluded that all the ministries having their web portals available and all 
the relevant contents on them, but the access was very poor. It was also noticed that all the web portals were providing one-way interaction either $\mathrm{G} 2 \mathrm{C}$. They need to provide the other model such as G2G and G2G transactional model. The quality of web portal may be improved by designing user friendly layout along with multi language facility. The technical skill professionals were available in the country but there was a need to fill the gap in the government departments a set of managerial level to strategic level. Legislation need to develop for the support of e-government in the country such as cyber law. The government develops the infrastructure which would support the backbone of the egovernment to provide the reliable services.

Huang and Fang [19] employed the analytical hierarchal process for analyzing the demand for Information services and their supply from Taiwan Government especially for remote areas. The study was conducted through surveys and a three phased survey was conducted in the first phase Egovernment's service information inquiry was done. In the second phase digital service information inquiry was done from people residing in reconstructed areas and third was of about inquiring about information services from reconstruction groups. As a result of this survey-based research digital divide in those areas was removed in a way that online information systems, VPNs, email services etc were established for people

Furuholt et al. [20] presented a study on the egovernment challenges and the role of political leadership in rural areas. According to the authors a strong leadership is necessary for implementing egovernment especially in rural areas. For proving the hypothesis Sragen, a village of Indonesia was taken under consideration and an exploratory study was done in this regard. Data collection was made by structured one to one interview and through unstructured in formal focus groups. Interview was conducted with the head of the district and the focus group workshops were made with the research persons, district heads, engineers and staff. Data filtration was made by applying a content analysis technique along with the deductive reasoning approach. From interviews and workshops they concluded that a strong leadership is necessary for the successful implementation of e-government because there are many technological and cultural changes which can affect the implementation of egovernment.

\section{Conceptual Framework}

In this paper the conceptual frame work represents the synthesis of literature review. It shows that how the certain variables used in the research is interrelated with each other. Figure 1 shows the research framework in which it is clearly seen that
Transformational Leadership is an independent variable, e-government is dependent variable, accountability and efficiency are mediators and transparency is moderator.

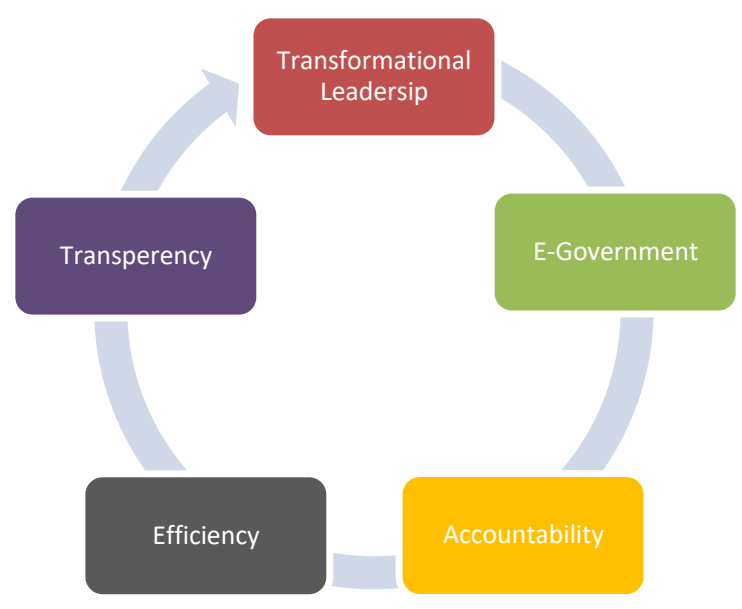

Figure 1. Conceptual Frame work

\section{Methodology}

After a thorough and extensive litrature review it is inferred that although everyone has put his efforts for the successful implementation of electronic government and they are successful to some extent but no one has emphasized on the impact of transformational leadership on electronic government with the utilization by enforcing transperency, efficiency and accountability. So the focus of our research is to proof that how and in what ways transformational leadership is making success in applying the e-government. For this purpose an inductive hypothsis approach was applied (Hume Fork a famous researcher called it an un justifieable approach even then he emphasized on the adoption of this approach because it always moves from specific to general and thus open more areas and dimentions of research in some specific domain) and a questionnaire was developed with a focus on four variables one independent, one dependent and one moderator and two mediators. Transformational Leadership is taken as independent variable and its direct and indirect impact is observed on egovernment. The impact is also observed through mediators and moderators. The major focus of data gathering was from public institutions, government offices, educational institutes, hospitals, students and teachers of different age groups, posts, jobs and qualifications. Research startegy was descriptive and quantitative data is gathered and a sample size was 288. The sampling technique is probabilty sampling.

\section{Data Analysis}


The data gathered through questionnaires. Three hundred questionnaires were circulated in the market, which included academia, public sector, private sector, semi government and unemployed professionals out of which 288 were recieved. The data was analysed using IBM SPSS version 24. There were five variables which were linked with the research directly or indirectly named as EGovernment (EG), Accountability (A), Efficiency (E), Transperency (T) and Transformational Leadership (TL). After the computation of variables the reliablity, skewness and kurtosis of computed data is statistically analysed. According to (Numally, 1978) the benchmark of reliability is 0.7 , skewness is \pm 1 and kurtosis is \pm 3 . Based on the above mentioned benchmark the reliability of data is 0.787 which is close to the benchmark value which means that the results are acceptable. Similarly the values obtained by computing the skewness and kurtosis are near to the benchmark values which validated the research data. Table 1 is showing the values of reliability, skewness and kurtosis that are obtained after the computation of data.

Table 1. Data Analysis

\begin{tabular}{|c|c|c|c|c|c|}
\hline Variables & $\begin{array}{c}\text { Reliability } \\
\text { Statistics }\end{array}$ & \multicolumn{2}{|c|}{ Skewness } & \multicolumn{2}{c|}{ Kurtosis } \\
\cline { 2 - 6 } & $\begin{array}{c}\text { Cronbach's } \\
\text { Alpha }\end{array}$ & Statistic & $\begin{array}{c}\text { Std } \\
\text { Error }\end{array}$ & Statistic & $\begin{array}{c}\text { Std } \\
\text { Error }\end{array}$ \\
\hline $\begin{array}{c}\text { All } \\
\text { Variables }\end{array}$ & 0.787 & - & - & - & - \\
\hline EG & - & -0.205 & 0.144 & 3.836 & 0.286 \\
\hline A & - & -1.495 & 0.144 & 4.607 & 0.286 \\
\hline E & - & -1.161 & 0.144 & 3.836 & 0.286 \\
\hline T & - & -0.855 & 0.144 & 3.393 & 0.286 \\
\hline TL & - & -0.181 & 0.144 & -0.065 & 0.286 \\
\hline
\end{tabular}

\section{Results}

Figure 2 shows that $80 \%$ population believes that tranformational leadership is compulsary for the successful implementation of electronic government through digital channels. $60 \%$ population believes that the implementation of e-government through transformational leadership will bring transperency, $40 \%$ beleve that it will bring accountability into the system and $28 \%$ believe that effiency in carring out certain processes will be enhanced. Thus it is proved that tranformational leadership has a positive impact on E-government.

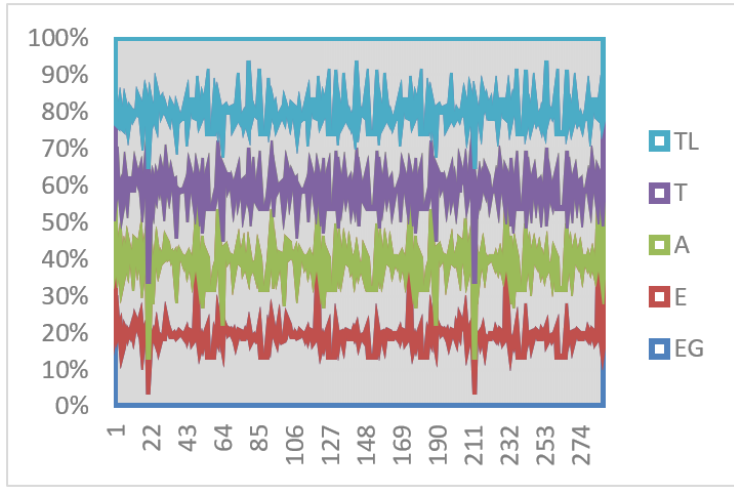

Figure 2. Results

\begin{tabular}{cccccc}
\hline \multicolumn{6}{c}{ Correlations } \\
\hline \hline & $E G$ & $E$ & $A$ & $T$ & $T L$ \\
\hline & 1 & & & &
\end{tabular}

$E G$

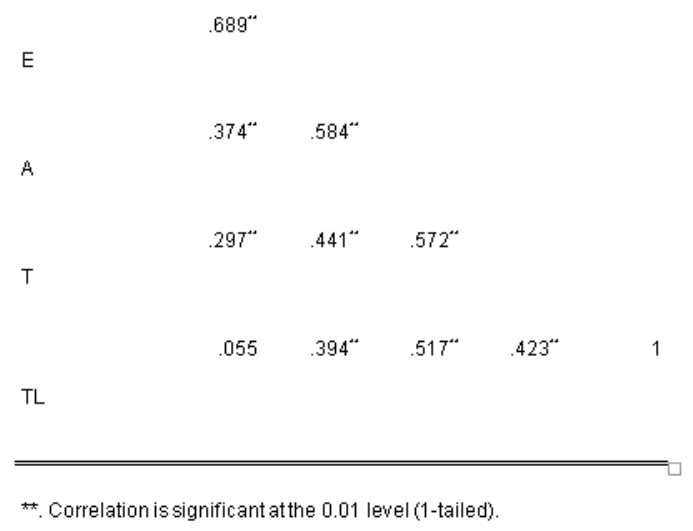

Figure 3. Correlation

The correlation table shows no significant results between transformational leadership and electronic government, but It shows significant results between efficiency, accountability and transparency which means that transformational leadership cannot implement electronic government directly unless or until transparency, accountability and efficiency can be achieved as shown in Figure 3.

To check mediation and moderation regression is checked it is found that the value of $\mathrm{R}$ square between Transformational leadership and efficiency by controlling electronic government is 0.47 , between accountability and transformational leadership is 0.14 and that of transparency and transformational leadership is 0.42 . The results are significant and shows that transformational leadership cannot directly affect e-government without the mediation of efficiency and accountability and moderation of transparency. 


\section{Conclusion}

Electronic government implementation is a very important aspect for the automation of various processes which take place among public and government. In this research the major focus was to implement electronic government through transformational leadership which will decrease the digital divide dilema and increase the usage of digital channels. The data analysis and results have shown that tansformational leadership is a backbone to achieve tranperency, accountability and efficieny by implementing electronic government system. This will bring a revolutionised change in the country

\section{References}

[1] Zhu, Y.Q., Kindarto, A., (2016), A garbage can model of government IT project failures in developing countries: The effects of leadership, decision structure and team competence. Published in Journal of Government Information Quarterly, Elsevier, No. 43, Sec. 4, pp 1-9.

[2] Ebbers, W.E, Jansen, M.G.M, Alexander, J.A.M., Deursen, V., (2016), Impact of the digital divide on egovernment: Expanding from channel choice to channel usage, published in Journal of Government Information Quarterly, Elsevier, 2016, pp 1-9.

[3] Jaeger, P.T., Thompson, K.M., (2016), E-government around the world: Lessons, challenges, and future directions. Published in Journal of Government Information Quarterly, Elsevier, Pp 389-394.

[4] Helbig, N., Gil-García, J.R., Ferro, E., (2009), Understanding the complexity of electronic government: Implications from the digital divide literature. Published in Journal of Government Information Quarterly, Elsevier, Pp $89-97$.

[5] Elnaghi, M., Alshawi, S., (2007), A Leadership Model for e-Government Transformation. Published in Proceedings of European and Mediterranean Conference on Information Systems.

[6] Germanakos, P., Samaras, G., Christodoulou, E., (2007), Multi-channel Delivery of Services - the Road from e-Government to m-Government: Further Technological Challenges and Implications.

[7] Andrian, R., Hendradjaya, B., Sunindyo, W.D., (2016), Software Assessment Model Using Metrics Products for eGovernment in The G2B Model, Fourth International Conference on Information and Communication Technologies (ICoICT), ISBN: 978-1-4673-9879-4 (c) 2016 IEEE

[8] Athukorala, C., Perera, I., Meedeniya, D., (2016), the Impact of Transformational and Transactional Leadership Styles on Knowledge Creation in Sri Lankan Software Industry, 978-1-5090-0645-8/16/IEEE.
[9] Yin, L., Jiahong, Z., (2014), The influence of the digital divide to the electronic government affairs, International Conference on Management of e-Commerce and e-Government, 978-1-4799-6543-4.

[10] Wickberg, S., (2013), Technological Innovations to identify and Reduce Corruption. Transparency International.

[11] AL-Hussaini, A., AL-Mutairi, N.N.M., Thuwaini, S.F., (2013), The Impact of Adopting E-Government on Reduce Administrative Corruption: Empirical Evidence from Kuwait's Public Sector, Academy of Contemporary Research Journal, volume 2, issue 2, pp. 31-43.

[12] Choueiri, E., Choueiri, G., Choueri, B., (2013), An Overview of E-government Strategy in Lebanon, International Arab Journal of E-Technology, volume 3, no. 1, 50-57.

[13] Hunnius, S., Schuppan, T., (2013), Competency requirements for transformational e-government, 46th Hawaii International Conference on System Sciences.

[14] Chander, S., Sharmila, (2012), E-Governance: Interoperability Issues, International journal of Research in Economics and Social Sciences, volume 2, issue 7, pp. 2237.

[15] Mistry, J., Jalal, A., (2012), An Empirical Analysis of the relationship between E-government and corruption, The International Journal of Digital Accounting and Research, volume 12, pp 145-176.

[16] Fu, Y., Xiao, K., (2012), The author's examined the Promoting Sustainable E-Government with Multichannel Service Delivery: A Case Study, Supported by the Doctoral Scientific Research Foundation of HUAT, 978-14673-2008-5/12/IEEE.

[17] Panda, P., Sahu, G.P., Gupta, P., (2010), Promoting Transparency and Efficiency in Public Procurement: EProcurement Initiatives by Government of India, 7th International Conference on E-government (ICEG).

[18] Kazmi, S.N.A., (2010), the factors influencing egovernance Implementation: issues and challenges in Pakistan, 978-1-4244-7571-1/10IEE.

[19] Huang, M.I., Fang, K., (2010), Reducing the Digital Divide of the Electronic Government of 921 Reconstruction Areas in Taiwan, IEEE.

[20] Furuholt, Bjoran, Wahid and Fathul, (2008), Egovernment Challenges and the Role of Political Leadership in Indonesia: A case of Sragen, Proceedings of 41st Hawaii International on Systems Sciences, pp. 1-10. 